\title{
O RESGUARDO NA GESTAÇÃO INDÍGENA AKWẼ XERENTE
}

\author{
Afonso Tĩ̃ kwa Xerente \\ Professor Alfabetizador \\ Roberto Sipkuze Xerente \\ Professor Alfabetizador
}

\section{ROWASKUKTURÊ}

Pikõ wasãwi tô simã sipsê si ĩpêhã simã sipsê kõwa zatô tmã tku nẽ, siwakru saĩ kõdi tpê pre - zawre (peixe pirara) tahã ku tê kmẽ si w aza ku aikde krẽ are dure zãhuri tê kmẽ siwa za ku dure aikde sahi pre snã twrahuk kãtô dure si nmõ dure siwakru tê krnẽ kõdi, nẽpre nẽhã tê kmẽ siwa za nẽpre tê tkrê sizus. Are ambâ tê hawi mhã tô kãnẽ, za dutre simã ro pibu kãnẽ aikuwa krmõwa tõ aitemã za ro tê sabu akwẽsto aimõ dasimã dat krwasku mnõze tê kmãdkã wa zatô tmã tkunẽ, wanẽku, zâ, tanõrĩ dam sipaki, kanẽ hawi, wanẽkum hêmba za ku aikde tkrê kuikãs are zâ zaku nẽs tmã hêmba nẽs siza, are tahã tmã hêmba kumnãstê zatô ambâ, aimõ azanã hêsu nã tsi kwa mõ are hêsu mẽ, are tanẽ re tmã hêmba wa za tô aikte ddêkwa sekwa kmẽ zaihâ tê hâizakur da tazi zatô rom hêmba sãmr are aikde tpês kãnẽ mãt Srêzdazute wam washu.

PALAVRAS-CHAVE: kraprepari. wasãroi; akwẽ sĩm pikõ.

\section{RESUMO}

Na gestação da mulher, tanto ela quanto o marido, devem manter um resguardo. O resguardo do pai da criança inclui, por exemplo, ele não poder ver certos tipos de animais. Caso o resguardo seja quebrado, ao nascer, a criança pode ser acometida por algum mal. Os Xerente, entretanto, conhecem meios de evitar esse mal.

PALAVRAS-CHAVE: gestação; resguardo; mulher akwẽ.

No dia primeiro de dezembro (01) de 2014, entrevistei o 
Sr. Sebastião Srêsdazute Xerente, na aldeia Salto Kripre, sobre o resguardo da gestação da mulher, como o homem pode manter o resguardo durante a gestação. Ele explicou muito bem. Segundo o Sebastião Srêsdazute Xerente, tem o homem fraco que não pode ver algum animal, do mato, como cobra, jacaré, peixe até abelha. Isso tudo homem tem que fazer o máximo possível para não encontrar ou nem pode ver e a mãe não pode comer qualquer caça também, como a cotia, algum pássaro juriti.

Segundo o Sebastião Srêsdazute Xerente, ao ver esses animais, não faz mal dentro da barriga da mãe, só acontece quando o bebê nascer, quando a criança estiver com um ano, aí vem o mal para criança. Se o pai vir a cobra sucuri, a criança é enrolada com a alma da cobra e a criança chora a noite inteira e dia inteiro. Assim acontece com os outros bichos se o pai vir. Então é muito valioso o pai ter muito cuidado de não ver esses animais.

Mas tem uma dica que o Sebastião Srêsdazute Xerente ensina quando o homem vir algum desses animais, aí tem que passar qualquer folha verde no rosto, rapidamente, na hora de ver, aí não tem perigo, porque, se passar essa folha, ao ver o animal, não corre o perigo. Disse também que tem pajé que dá voltas nesses casos para curar a criança, mas não são todos os pajés que podem fazer essa cura, por isso é muito perigoso.

O resguardo da mãe é não comer qualquer animal, peixe ou pássaro. A mãe, ao comer cotia, o cabelo da criança fica avermelhado igual o cabelo da cotia. Ao comer a juriti, a criança fica remedando a juriti. Tem também o resguardo para peixe, ou seja, tinguizada, a pescada na tinguizada. Se o rapaz está com a esposa grávida, aquele rapaz pode ir bem atrás dos outros, não pode ir juntamente com os outros, e ele tem que falar para o pajé que realmente a sua esposa esta grávida. Aí o pajé amarra uma cordinha no pescoço, no braço, nas pernas, ou então o pajé passa o carvão no rosto, porque, se não fizer isso, os peixes não se embebedam e não morrem muitos peixes, pois é muito importante fazer resguardo das pikõ (mulher) no povo Xerente, porque é muito perigoso.

Ele fala do homem fraco ao ver esses animais, é muito mais fácil de passar para a criança após nascer, mas o homem forte pode ver não acontecer nada. Ele pode ver não passar para criança. Assim 
cada homem pode se conhecer, só anotar ao ver algum animal, quando a sua esposa esta grávida. Assim, quando a criança nascer e crescer sem nada acontecer, aí o pai pode falar um homem forte. Aí ele pode ver todos os bichos. Somente na pescaria é obrigatório se amarrar ou passar o carvão seja fraco ou forte. Mas o homem fraco, se vir algum animal, assim que a criança nascer passa para criança e aí o pai se conhece que é fraco de ver os animais do mato. 